SVERIGES RIKSBANK

WORKING PAPER SERIES

231

Evaluating Microfoundations for Aggregate Price Rigidities: Evidence from Matched FirmLevel Data on Product Prices and Unit Labor Cost

Mikael Carlsson and Oskar Nordström Skans

AUGUST 2009 
WORKING PAPERS ARE OBTAINABLE FROM

Sveriges Riksbank • Information Riksbank • SE-103 37 Stockholm Fax international: +4687870526

Telephone international: +4687870100

E-mail: info@riksbank.se

The Working Paper series presents reports on matters in the sphere of activities of the Riksbank that are considered to be of interest to a wider public.

The papers are to be regarded as reports on ongoing studies and the authors will be pleased to receive comments.

The views expressed in Working Papers are solely the responsibility of the authors and should not to be interpreted as reflecting the views of the Executive Board of Sveriges Riksbank. 


\title{
Evaluating Microfoundations for Aggregate Price Rigidities: Evidence from Matched Firm-Level Data on Product Prices and Unit Labor Cost.*
}

\author{
Mikael Carlsson ${ }^{\dagger}$ and Oskar Nordström Skans ${ }^{\ddagger}$ \\ Sveriges Riksbank Working Paper Series No. 231 \\ August 2009
}

\begin{abstract}
Using data on product-level prices matched to the producing firm's unit labor cost, we reject the hypothesis of a full and immediate pass-through of marginal cost. Since we focus on idiosyncratic variation, this does not fit the predictions of the Maćkowiak and Wiederholt (2009) version of the Rational Inattention Model. Neither do we find that firms react strongly to predictable marginal cost changes, as expected from the Mankiw and Reis (2002) Sticky Information Model. We find that, in line with Staggered Contracts models, firms consider both the current and future expected marginal cost when setting prices with a sum of coefficients not significantly different from unity.
\end{abstract}

Keywords: Price Setting, Business Cycles, Information, Micro Data.

JEL classifications: D8, E3, L16.

\footnotetext{
*We are grateful to Ricardo Reis, Mathias Trabandt, Karl Walentin, Andreas Westermark and members of the Eurosystem Wage Dynamics Network as well as seminar participants at the Budapest Economic Seminar Series, Uppsala University and the Riksbank for useful discussions. We would also like to thank Erik von Schedvin for excellent research assistance and Jonny Hall and David Roodman for helpful advice. The data used in this paper are confidential but the authors' access is not exclusive. The views expressed in this paper are solely the responsibility of the authors and should not be interpreted as reflecting the views of the Executive Board of Sveriges Riksbank.

${ }^{\dagger}$ Research Department, Sveriges Riksbank, SE-103 37, Stockholm, Sweden. E-mail: mikael.carlsson@riksbank.se

${ }_{\ddagger}^{\ddagger}$ Institute for Labour Market Policy Evaluation (IFAU), Uppsala University and IZA. Address: IFAU, P.O. Box 513, SE-751 20 Uppsala, Sweden. E-mail: oskar.nordstrom_skans@ifau.se
} 


\section{Introduction}

A set of competing business cycle models has recently emerged that can all explain why nominal shocks have real effects. ${ }^{1}$ Although sharing a large number of common features, a key difference between these models lies in the assumptions of how firms set prices and process information. Yet, there exists very little direct micro evidence on the credibility of these assumptions. This paper uses detailed data on product prices and unit labor cost merged at the firm level to evaluate competing sets of assumptions regarding firms' price-setting behavior. Thereby, we provide evidence on the empirical relevance of the microfoundations of different DSGE models.

The bulk of recent research on aggregated fluctuations focuses on staggered contracting at the micro level, and the implied forward looking price-setting behavior, building on the work by Fischer (1997), Taylor (1980), Calvo (1983) and others. The supply block of this workhorse macro model rests on a firm-level pricing equation relating the optimal reset price to a discounted sum of today's and future expected marginal cost. ${ }^{2}$ Aggregating across firms yields the New Keynesian Phillips Curve which relates inflation to expected inflation and (aggregate) real marginal cost. ${ }^{3}$

Recently, a literature has emerged centered around the idea of Phelps (1970), first formalized by Lucas (1972), that real effects of nominal disturbances stem from imperfect information. In a proposal to replace the New Keynesian Phillips Curve, Mankiw and Reis (2002) suggest that information, rather than prices, is sticky. In their model, a firm updates its information set with a fixed probability in each period and, when updating, decides upon a price path which will remain in place until the next time information has been received. Thus, nominal disturbances have real effects due to information staggering and not due to price staggering.

Maćkowiak and Wiederholt (2009) propose a third alternative model, building on work by Sims (1998, 2003), where (some) information also disseminates slowly. Once more, prices can be freely changed by the firm in any period, but the firm faces a constraint on the amount of information that can be processed in each time period. This forces the

\footnotetext{
${ }^{1}$ As indicated by a large empirical literature; see e.g. Christiano, Eichenbaum, and Evans (1999) and references therein.

${ }^{2}$ See e.g. Smets and Wouters (2003), Christiano, Eichenbaum, and Evans (2005), Adolfson, Laséen, Lindé, and Villani (2008) and others for examples of the workhorse model.

${ }^{3}$ See e.g. Woodford (2003) for a detailed derivation.
} 
firm to make an (optimal) choice about the relative attention to be paid to idiosyncratic versus aggregate conditions based on their relative volatility. In the Maćkowiak and Wiederholt (2009) version of the "Rational Inattention Model", the firm allocates almost all its attention to idiosyncratic conditions. This gives rise to a situation where firms react as strongly and as quickly to idiosyncratic conditions as if they had perfect information (i.e., as in a frictionless model). In contrast, firms react in a dampened and delayed fashion to aggregate conditions, once more giving rise to real effects of aggregate nominal disturbances. ${ }^{4}$

Although all the above models can explain why nominal shocks give rise to real effects, they do differ in their lessons for monetary policy; see Reis (2008) or Maćkowiak and Wiederholt (2009) for a discussion. Thus, it is important to collect evidence on which set of microfoundations (if any) is in line with the data. The key novelty in this paper is that we evaluate the empirical relevance of these different microfoundations directly at the micro level. This is done using very detailed Swedish data on product producer prices matched to a rich data set containing information on the activity of the firms that set these prices. Using our firm-level data, we construct a measure of marginal cost (i.e., unit labor cost), consistent with the bulk of macro models in the literature. To our knowledge, this is the first time such detailed quantitative price data have been merged with detailed information on firm-level activity for a broad sample of firms. ${ }^{5}$ The matched data set contains 17, 282 price observations (with at least a spell length of two periods) across 1,610 unique product codes and 3,510 unique product/firm identities produced by 702 industrial firms. ${ }^{6}$ These firms are mainly medium to small firms, with an average of 65 employees.

Since marginal cost is unlikely to be exogenous, we use Instrumental Variable (IV)/Generalized Methods of Moments (GMM) methods. Beside internal instruments (i.e. lags), we also exploit variations in factor market conditions between competing firms using data on all Swedish employment spells in the private sector matched with detailed characteristics of each individual employee. To obtain an instrument correlated with the firms' marginal costs, but unrelated to the firms' decisions, we use regional variation in

\footnotetext{
${ }^{4}$ In related work, Woodford (2002) proposes a model in which the firms face a signal-extraction problem where they pay little attention to aggregate conditions.

${ }^{5}$ Lundin, Gottfries, Bucht, and Lindström (2007) use a similar Swedish data set (but with a plant-level producer price index instead of product prices) to estimate a customer-markets model.

${ }^{6}$ The industrial sector constitutes about 30 percent of total private sector GDP in Sweden.
} 
predicted wages over time for workers with different skills to derive the market valuation of the (lagged) skill composition of each firm.

Using IV/GMM methods and focusing on idiosyncratic variation, ${ }^{7}$ we find that the data forcefully reject the text-book hypothesis that the firm should set its price as a markup over marginal cost with an immediate and full pass-through. Instead, we find a price-cost elasticity of about one third. This incomplete adjustment to idiosyncratic marginal cost changes is also inconsistent with the Maćkowiak and Wiederholt (2009) version of the Rational Inattention Model, which predicts a full and immediate price response to idiosyncratic movements in marginal cost. On the other hand, the result is consistent with nominal frictions such as in a Staggered Contracting Model. Then, we proceed by estimating the Calvo (1983) pricing equation, which is the key underlying pricing relationship in the workhorse macro model. We find that the data do support that firms consider both current and future expected marginal cost when setting prices. Furthermore, the estimated parameters are reasonable as compared to what is expected from both macro and micro studies. Also, as expected from the Calvo (1983) model, the sum of coefficients is not significantly different from unity. The lack of a full passthrough of observed marginal cost onto prices is also consistent with the Mankiw and Reis (2002) Sticky Information Model, since this model assumes that firms are not fully aware of their current marginal cost, except when drawn to update their information set. To test the Mankiw and Reis (2002) Sticky Information Model, we rely on their baseline calibration of the information-stickiness parameter to determine the fraction of informed firms. However, we do not find that firms react strongly to marginal cost changes that could have been predicted by the vast majority of information vintages of firms. In fact, lagging the instruments set backwards does not affect the point estimates of the passthrough of marginal cost onto the price to any noticeable extent. Thus, the data do not support the idea that information is sticky in the Mankiw and Reis (2002) sense.

This paper is organized as follows: Section 2 discusses related literature. Section 3 outlines the various price-setting models we consider. Section 4 describes the data and discusses our empirical strategy and Section 5 reports the results. Finally, section 6 concludes the paper.

\footnotetext{
${ }^{7}$ That is, we include sector-specific time dummies and look at the relative price reactions to idiosyncratic variation in marginal cost.
} 


\section{Related Literature}

Considerable effort has been put into studying the macro implications of staggered contracts and evaluating the empirical performance of the New-Keynesian Phillips curve. See e.g. Galí and Gertler (1999), Galí, Gertler, and López-Salido (2001), Lindé (2005) and Sbordone (2002) and, in a full system setting, e.g. Smets and Wouters (2003), Christiano, Eichenbaum, and Evans (2005) and Adolfson, Laséen, Lindé, and Villani (2008). Overall, the New Keynesian Phillips curve seems to provide a reasonable account of inflation dynamics, although whether a hybrid version with backward looking as well as forward looking terms is needed is still an open issue.

Mankiw, Reis, and Wolfers (2003) find evidence in support of the Sticky Information Model using survey data on inflation expectations. However, Coibion (2007) tests the empirical relevance of sticky prices relative to sticky information on macro data and finds that, conditional on historical inflation forecasts, the Sticky Information Phillips Curve is statistically dominated by the New Keynesian Phillips Curve. However, there still exists little empirical work on evaluating the Rational Inattentions Models since the achievement of Maćkowiak and Wiederholt (2009) of incorporating a rational inattention mechanism into a DSGE setting is very recent. Boivin, Giannoni, and Mihov (2009) present US sectoral and aggregate evidence that supports the Maćkowiak and Wiederholt (2009) model by finding a fast reaction to sectoral shocks, but prolonged responses to aggregate shocks. Maćkowiak, Moench, and Wiederholt (2008) also report a fast response of sectoral prices to a sectoral disturbance, in contrast to a prolonged response stemming from an aggregate disturbance.

On the micro side, research has been focused on the behavior of price adjustment for particular products in terms of the size and frequency of price changes or the duration of fixed price spells and its implications for different models of price setting; see e.g. Bils and Klenow (2004), Klenow and Kryvtsov (2008), Nakamura and Steinsson (2008), Álvarez et. al. (2006), Dhyne et. al. (2006), Vermeulen et. al. (2007) and others. Another strand of the literature has been focusing on asking firms about their price-setting practices in surveys, see e.g. Blinder, Canetti, Lebow, and Rudd (1998), Apel, Friberg, and Hallsten (2005), Druant et. al. (2008), Fabiani et. al. (2006) and others. Although informative regarding firm price-setting behavior in general, the results from these studies cannot fully discriminate between the different sets of proposed microfoundations since one dimension 
of the problem is missing. Due to the lack of linked data sets, very few papers have managed to relate the cost faced by an individual firm to the prices set by these firms. Two exceptions are Buckle and Carlson (2000) and Loupias and Sevestre (2008), although these studies rely on qualitative price and cost information (up, same, down, or more elaborate), thus restricting the analysis to estimating ordered probits. ${ }^{8,9}$

The key novelty in this paper is that quantitative price data on the product level have been merged with information on the producing firm's production level, inputs and costs. The frequency of the data is annual, so we are unable to study the duration of price spells in detail, but we do observe price spells with a duration above one year in the data. The quantitative nature of the data implies that we can study the size of the pass-through of marginal cost onto the price and to what extent past expectations of current outcomes, or current expectations of future outcomes, are of importance for pricing decisions. In contrast, the data are not very well suited for evaluating models with fixed costs of price change (menu costs). This type of analysis would entail estimating probability models of the price change decisions, but the annual frequency of the data implies that there is only a moderate share of observations with unchanged prices. Thus, evaluating this type of models is left to future research.

\section{Theory}

If the firm, indexed by subscript $f$, has any price-setting power in the product market, the optimal frictionless price at time $t, P_{f, t}$, is set as a markup, $\mu_{f, t}$, over marginal cost, $M C_{f, t}$, i.e. ${ }^{10}$

$$
P_{f, t}=\mu_{f, t} M C_{f, t} .
$$

Moreover, since cost minimization implies that, at the optimum, the cost associated with each possible margin of adjustment should be the same, it is sufficient to only look at one

\footnotetext{
${ }^{8}$ It should be noted that Loupias and Sevestre (2008) also merge their data with quantitative information on average firm-level base wages.

${ }^{9}$ There is also a micro-data literature relating retail prices to costs (wholesale/spot prices for the vended product); see e.g. Levy, Dutta, and Bergen (2002), Davis and Hamilton (2004) and Eichenbaum, Jaimovic, and Rebelo (2008) or, taking a broader perspective, looking at detailed PPI or CPI data for components with a low value added and constructing input cost using an input-output table; see e.g. Peltzman (2000).

${ }^{10}$ For expositional ease, we initially assume that the firms only produce a single product.
} 
of them. Here, we focus on the labor-input margin. Marginal cost can then be written as

$$
M C_{f, t}=\frac{\partial \operatorname{Cost}_{f, t}}{\partial L_{f, t}} \frac{\partial L_{f, t}}{\partial Y_{f, t}}
$$

where $L_{f, t}$ denotes labor input. Following Bils (1987), Rotemberg and Woodford (1999) and others, we assume the following production function

$$
Y_{f, t}=\left(Z_{f, t} L_{f, t}\right)^{\alpha} g(\text { Other Factors of Production } \text { Pr,t }) \text {, }
$$

where $Z_{f, t}$ denotes labor augmenting technical change. ${ }^{11}$ Given expression (3), equation (2) can be rewritten as

$$
M C_{f, t}=\frac{\partial(\text { Wage Bill })_{f, t}}{\partial L_{f, t}}\left(\frac{1}{\alpha} \frac{L_{f, t}}{Y_{f, t}}\right)
$$

Then, assuming that firms are wage takers in the local labor market and denoting the average wage (across the skill composition of the employees) for firm $f$ at time $t$ as $W_{f, t}$, we arrive at

$$
M C_{f, t}=\frac{1}{\alpha} \frac{W_{f, t} L_{f, t}}{Y_{f, t}}=\frac{1}{\alpha} \frac{(\text { Wage Bill })_{f, t}}{Y_{f, t}}
$$

showing that marginal cost is proportional to unit labor cost.

Taking logs, and assuming that the firm faces an iso-elastic demand function, we arrive at the frictionless model, where we now allow for firms selling several products, as in the data, by introducing index $g$ which indexes unique products by firm $f$

$$
\ln P_{g, t}=\gamma_{g}+\ln M C_{f, t},
$$

where $\gamma_{g}$ is the log of the possibly product-specific time invariant markup. ${ }^{12}$ Note that marginal cost movements will have an immediate and full pass-through onto prices in the frictionless model.

Maćkowiak and Wiederholt (2009) outline a model where prices can be freely changed in any period, but the firm faces a constraint on the amount of information that can

\footnotetext{
${ }^{11}$ Note that this production function is slightly more general than a Cobb-Douglas function.

${ }^{12}$ Here, we need to assume that the marginal cost is the same across all products. Since this may not be true, this will provide a source of error in the empirical implementation. However, since we will employ an IV-approach in the empirical work, this problem should be of minor importance.
} 
be processed at each point in time. This forces the firm to make a choice about the relative attention to be paid to idiosyncratic versus aggregate conditions based on the relative volatility of these conditions. Maćkowiak and Wiederholt (2009) calibrate their model to match micro-evidence on prices (i.e. the average absolute size of price changes) resulting in an outcome where firms allocate 96 percent of their attention to idiosyncratic conditions. This gives rise to firms reacting as strongly and as quickly to idiosyncratic conditions as if there were perfect information. In contrast, the firm reacts in a dampened and delayed fashion to aggregate conditions. Thus, the firm's reaction is very much dependent on the type of conditions that have changed. To take this prediction to the micro data, we estimate the empirical version of (6) to see if the parameter on $\ln M C_{f, t}$ is close to unity when we let sector specific-time dummies remove all but the idiosyncratic movements from the analysis. Removing all sectoral movements implies that we look at relative-price responses to idiosyncratic movements in the marginal cost.

In the recent macroeconomic literature, the dominant paradigm for considering the relationship between price setting and marginal-cost dynamics is Calvo (1983) style nominal rigidities. In the Calvo model, the firm is allowed to reset the price with probability $(1-\theta)$ in each period, whereas it is stuck with the old price with probability $\theta$. The firm's first-order condition in a Calvo-economy is

$$
\ln P_{g, t}=\gamma_{g}+(1-\theta \beta) E_{t} \sum_{k=0}^{\infty}(\theta \beta)^{k} \ln M C_{f, t, t+k},
$$

where $P_{g, t}$ is the optimal reset price for the firm at time $t$, and $\gamma_{g}$ is once more the $\log$ of the firm's (product-specific) markup. ${ }^{13}$ Moreover, $\beta$ is the discount factor and $E_{t} M C_{i, t, t+k}$ denotes the expectation taken at time $t$ of (nominal) marginal cost of firm $i$ at time $t+k$ when the price was last reset at time $t$. Thus, the price is set as a markup over the weighted average of the discounted stream of marginal costs, where the weight on the $k$ :th term reflects the probability of being stuck with the reset price $P_{i, t}$ for $k$ periods ahead. Note that in the limiting case of complete price flexibility $(\theta \rightarrow 0)$, the price will just be a markup over current marginal cost, i.e. (7) converges to expression (6). Thus, the future is only of importance if there are impediments to continuous price adjustments.

\footnotetext{
${ }^{13}$ See e.g. Galí, Gertler, and López-Salido (2001).
} 
Mankiw and Reis (2002) instead suggest that information (rather than prices) is sticky due to intermittent information updating. In the Mankiw and Reis (2002) Sticky Information Model, a firm updates its information set with a fixed probability each period and then, when updating, decides upon a price path which will remain in place until the firm is drawn to update the next time. The firm's optimal price in period $t+k$ is then given by

$$
\ln P_{g, t+k}=\gamma_{g}+E_{t-r} \ln M C_{f, t+k}
$$

where $t+k$ denotes period $t+k$ in the firm's price plan, $t-r$ is the time period when the information set was last updated and $\gamma_{g}$ is the log of the firm's (product-specific) markup. ${ }^{14}$

\section{Data and Empirical Strategy}

Next, we turn to discussing the data as well as the empirical strategy we rely on to take the models, described above, to the data.

\subsection{Data}

The data we use in this paper are drawn from the Swedish "Industrins Varuproduktion" (IVP) survey for detailed product-price data that can be linked to the producing plant, the "Industristatistiken" (IS) survey for information on plant-level activity. Finally, the Register Based Labor Market Statistics data base (RAMS) provides information on each individual employee in each plant as well as for all other employees in the private sector.

The IVP survey provides annual information on prices and quantities of products produced for all industrial plants with at least 10 (20) employees for the years 1990 - 1996 $(1997-2002)$ and a sample of smaller plants. The product classification is at the finest (i.e., the 8/9-digit) level of the Harmonized System (HS) for the years 1990-1995 and for the Combined Nomenclature (CN) for the years 1996 - 2002. The CN is the EU's coding system for classifying products for customs and statistical purposes. This classification is, in turn, based on the HS, which is also the basis for the import and export codes used in

\footnotetext{
${ }^{14}$ See Trabandt (2007) for a discussion on the optimal pricing behavior of a firm in a Sticky Information Model.
} 
the US. ${ }^{15}$ These data are quite unique and it is therefore important to note a few points. First, the (per unit) price data are calculated from yearly reported values and volumes of products sold within each product code stated by the firm. ${ }^{16,17}$ The data are thus based on actual transaction prices and not list prices, which may behave very differently. However, the data do not allow us to control for the customer composition over time. Second, given the very fine level of classification, we can actually follow the same product, or at least a very closely defined group of products, over time. To see the level of detail at the finest level of the product code, it is instructive to look at examples of descriptive texts. As such an example, product code 84181010 refers to " $A$ combined freezer and cooler with separate exterior doors with a volume exceeding 340 liters intended for use in civilian aircrafts". It should be kept in mind, though, that changes in products within a product group or changes in the composition of buyers may lead us to overestimate the frequency of price changes. ${ }^{18}$

Since the raw price data involve a few very large swings, we apply a cleaning procedure for the data used in the final analysis. To remove the impact of this type of observations on the results, we split the individual price series and give them a new unique plantprice identifier whenever a large change in the growth rate appears in the raw data. We use the full raw-data distribution of all price changes that we can match to the firms in the IS data to determine the cut-off levels as given by the 1.5 and 98.5 centiles of this distribution. See Appendix A for more details where we also discuss experiments with changing the cut-offs.

A key novelty in this paper is that these data can be matched to data on activity for the individual plant from the IS survey. This survey contains annual information for the years 1990 - 2002 on inputs and output for all Swedish industrial plants with 10 employees or more and a sample of smaller plants. We only keep plants that are also a firm since pricing is essentially a firm and not a plant-level decision. There may also be some scope for transactions between plants within a firm for tax reasons. In addition, we

\footnotetext{
${ }^{15}$ See appendix A for more details about handling this change in the coding system and other details.

${ }^{16}$ There is no flag for sales in the data but, as noted by Nakamura and Steinsson (2008), sales seem to be uncommon in producer price data.

${ }^{17}$ Moreover, the price change we observe may be the result of several price changes. Naturally, this is the case for all data that are not measured in real time.

${ }^{18}$ This is a problem of varying importance, however. For example, in a regression of product price on marginal cost, measurement errors in the product price will only affect standard errors and will not give rise to any bias for the point estimate.
} 
limit the analysis to continuing firms since we want to identify "normal" behavior.

From the IS survey, we have information about the firm's wage bill which we will use to construct unit labor cost. ${ }^{19}$ Moreover, from the IS survey, we collect our measure of nominal output, defined as the value of total sales. This measure is deflated with a firmspecific producer price index to obtain a measure of real output, $Y_{i, t}$. The firm-specific price index we use is a Paasche index, constructed using a combination of the plant-specific unit prices, described above, and the most detailed producer-price indices available. The producer-price index for the relevant class of products is used if the 8/9-digit unit value data are not available due to missing data or changes in the firm's product portfolio, or if the price change is one of the 1.5 percent most extreme price changes observed in any tail of the raw data distribution of log price changes (consistent with how we treated individual price changes above).

After constructing the firm-level variables, we remove firms which are subject to large swings in the observed marginal cost. Once more, this is done in order to capture normal behavior and not the behavior of firms in extreme circumstances. Similarly, as with prices, we use the full distribution of log changes in unit labor cost across all firms for which this variable can be computed and remove firms with growth rates outside the $[1.5,98.5]$ centiles in any year.

When merging data sets, we are left with 17, 282 price observations (with a minimum spell length of two periods) across 1, 610 unique product codes, 3, 510 unique product/firm identities and 702 firms. These industrial firms are mainly medium to small firms with an average of 65 employees (see appendix A for more details).

In figure 1, we plot the final data distribution of log price changes (for the 8/9-digit unit value data). All in all, this comprises 13,772 price change observations. Each bin represents a log difference of 0.01 . Note that since these prices are calculated from reported values and volumes of sold products, there might be small rounding errors in the data. However, as can be seen in figure 1, there is a substantial spike for the bin centered around zero. In fact, 13.6 percent of the price-change observations are confined within the \pm 0.5 percent interval, thus implying a considerable amount of very small price changes.

\footnotetext{
${ }^{19}$ Throughout the analysis, we focus on the wage bill net of payroll taxes. These taxes are proportional to the wage bill and in our empirical approach, we will include a dummy setup that fully captures the impact of proportional taxes.
} 


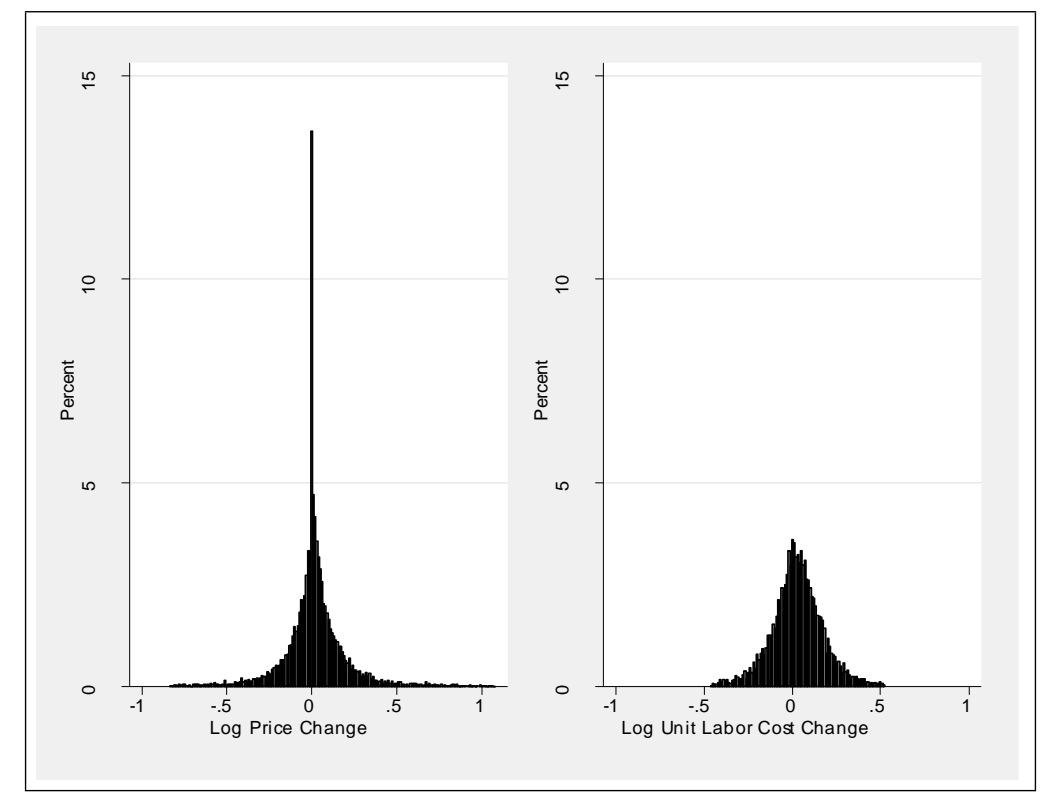

Figure 1: Histograms of final data. The left-hand panel describes the distribution of log price changes across 13, 772 observations (for 1,610 different products across 702 firms). The right-hand panel describes the distribution of log unit labor cost changes across 8,424 observations (for 702 firms). Bin size 0.01.

The observation of a quite substantial part of fixed prices across years is well in line with the survey evidence. When surveying 626 Swedish firms in 2002, Apel, Friberg, and Hallsten (2005) found that about 70 percent of the firms adjust their price once a year or less often. Moreover, for the approximately 15,000 European firms surveyed in the Eurosystem Wage Dynamics Network (WDN), Druant, Fabiani, Kezdi, Lamo, Martins, and Sabbatini (2008) report that about half of the firms change their price once a year or less frequently on average.

The spike at zero gives a first indication of the presence of price rigidities. However, the observation of fixed price spells is not ironclad proof of price rigidities per se since marginal cost may not have moved. This is something to which we turn below.

The log price-change distribution is right skewed (skewness coefficient of 0.46) and highly leptokurtic (a kurtosis coefficient of 8.62). ${ }^{20}$ It is also interesting to note that the mean price change in these data is close to the inflation rate computed for Swedish industry, 1.8 in the sample and 1.9 percent in the aggregate. However, the median log price change is almost zero, 0.003 . To look at the persistence in the relative prices, we run

\footnotetext{
${ }^{20}$ Some caution should be observed when interpreting the skewness and kurtosis numbers here since we have manipulated the tails of the raw data distribution.
} 
an $\mathrm{AR}(1)$ in the log price, while controlling for fixed product effects and the interaction of year and two-digit sector-code (NACE) dummies. This yields a coefficient of 0.546 (with a standard error of 0.234$)^{21}$ which thus points towards fairly persistent dynamics in relative prices, but is still mean reverting.

In the right-hand panel of figure 1, we plot the distribution of log changes in unit labor cost for the 702 firms (all in all 8,424 observations). As can be seen in the figure, there is no corresponding spike at a zero unit labor cost change. ${ }^{22}$ Thus, the data do support the view that the spike in the price-change distribution is an indication of nominal price rigidities. Looking at skewness and kurtosis statistics of the unit labor cost change distribution, we can see that this distribution is more symmetric (a skewness coefficient of 0.01) and much less peaked (the kurtosis coefficient equals 3.82). The mean log unit labor cost change is equal to 0.027 and the median is about $0.025 .{ }^{23}$ To study the persistence in relative unit labor cost, we run an $\mathrm{AR}(1)$ in log marginal cost, while controlling for fixed firm effects and the interaction of year and two-digit sector code dummies. This yields a coefficient of 0.542 (and a standard error of 0.04). ${ }^{24}$ Since we found that the relative price was mean reverting, it is reassuring to see that relative unit labor cost is also mean reverting. In addition, the dynamics for the relative unit labor cost is very similar to that of relative price.

\subsection{Instrumentation}

To obtain an empirical version of the frictionless model (6), we add a free parameter on the marginal cost term as well as an error term. The error term can be interpreted as a markup shock. Consequently, it will be correlated with marginal cost unless the marginal

\footnotetext{
${ }^{21}$ We use the Arellano and Bond (1991) bond estimator with lagged (2-9) log prices as instruments. We impose the restriction that the relationships in the "first stage" are the same across all time periods, i.e. we collapse the instrument set (see e.g. Roodman, 2006, for a discussion). The standard error is the robust standard error from the first stage. Including the full history in the instrument set does not change the results. Including a second lag yields a small and insignificant point estimate for this additional term.

${ }^{22}$ In fact, there are only three observations with exactly zero growth in marginal cost, whereas the corresponding number for price changes is 529 .

${ }^{23}$ Note that since a firm can sell more than one product, these numbers cannot be directly compared to the above inflation rates.

${ }_{24}^{4}$ Once more, we use the Arellano and Bond (1991) bond estimator with a lagged (2-9) log marginal cost and (1-9) of the projected marginal cost as instruments and collapse the instrument set. The standard error is the robust standard error from the first stage. Including the full history in the instrument set does not change the results. Including a second lag yields a very small point estimate for this additional term.
} 
cost curve is flat. Then, we need instruments to identify the causal effects of changes in marginal cost on price-setting behavior. Similarly, in order to handle expectations when taking the Calvo and the Mankiw Reis models to the data, we will also need to rely on instruments (see section 4.3 below).

One approach that we will employ is to use internal instruments (i.e. lags of dependent variables). However, we also construct instruments based on local labor market wage variation and the firm-specific labor force composition using data for all employees in the private sector (RAMS) which can be linked to firm-level data.

For our purposes, it is useful to consider the wage bill as the product of (i) the number of employees across different worker types and (ii) the average market wage for each such type, where each type is defined by a vector of skill characteristics (age, education etc.). Thus, we rewrite the marginal cost measure in (5) as

$$
M C_{f, t}=\frac{1}{\alpha} \frac{\mathbb{W}_{j, t} \mathbb{L}_{f, t}^{\prime}}{Y_{f, t}}
$$

where $W_{j, t}$ is a (row) vector of wages for different types of workers in the local labor market $j$ from which firm $f$ hires workers. Moreover, $L_{f, t}$ is a (row) vector where each element contains the number of employees of firm $f$ across these worker types in period t. This marginal-cost measure thus corresponds to the cost of expanding labor input with an unchanged composition of worker types. This is a natural extension of the macro approach outlined by e.g. Rotemberg and Woodford (1999) when thinking about marginal cost measurements in a micro-data setting. The "external" instrument we construct is the cost associated with expanding on the number-of-employees margin while fixing the initial composition of workers, evaluated at local market wages and the initial level of output. To this end, we use the employment composition within the firm observed in November the previous year as well as last year's output level.

The data we use to construct local market wages cover the period $1989-2002$ and contain information about annual labor earnings for all privately employed workers in Sweden. The raw data were compiled by the Swedish Tax Authority in order to calculate taxes. The data include information on annual earnings as well as the first and last remunerated month for each employee from each firm. Using this information, we can construct a measure of monthly wages for each employee in each of the firms in our 
sample. ${ }^{25}$ Moreover, individual characteristics have been added for each employee. These stem from various databases maintained by Statistics Sweden and include Age, Gender, Education (both four-digit field and three-digit level codes building on ISCED 97) and Immigration Status (by seven regions of origin). Since each employment spell is associated with a firm, we can observe to which sector and local labor market the spell pertains. ${ }^{26}$

To obtain the local market wage in period $t$ as a function of observable characteristics, we estimate the following Mincer-type equations on $(\log )$ observed wages for all full-time employees in the private sector for each local labor market in period $t$

$$
\ln W_{l, t}=\Theta\left[\begin{array}{l}
\text { Sex }_{l}, \text { Age }_{l, t}, \text { Age }_{l, t}^{2}, \text { Age }_{l, t}^{3}, \text { Education } \text { Level }_{l, t}, \\
\text { Education Field }_{l, t}, \text { Imigrant Status }_{l}, \text { Sector }_{l, t}
\end{array}\right]
$$

where $l$ indexes individual workers. Using $\hat{\Theta}$ we can then obtain the period $t$ local labormarket valuation for each worker cell in the initial distribution. This procedure is repeated for each year in the sample. We thus use a very broad data set to estimate the market valuation. Then, we check whether the individual firm's degree of monopsony power in the local labor market for a certain cell is a concern. Finally, we divide the projected wage sum by lagged output, which we use as a measure of the initial output level. Thus, we treat lagged output as predetermined. All in all, we can write our instrument, which we label the Projected Marginal Cost, as

$$
\widehat{M C}_{f, t}=\left(\frac{\widehat{\mathbb{W}}_{j, t} \mathbb{L}_{f, t-1}^{\prime}}{Y_{f, t-1}}\right),
$$

where $\widehat{\mathbb{W}}_{j, t}$ is a (row) vector of predicted market wages for different cells of worker characteristics in the local labor market $j$ and $L_{f, t-1}^{\prime}$ is a (column) vector where each element

\footnotetext{
${ }^{25}$ The data lack information on actual hours, so to restrict the attention to workers that are reasonably close to full time workers, we only consider a person to be a full-time employee if the (monthly) wage for November exceeds 75 percent of the mean wage of janitors employed by municipalities. We only include employment spells that cover November since, given the labor market flows, we must choose one month on which to focus and, given the instrument we want to construct, we should focus on a month late in the year. Since December is influenced by Christmas holidays we choose to focus on November (following the practice of Statistics Sweden). Moreover, we only count an individual as employed by one firm at most each year by only keeping the employment with the highest wage. Thus, in other words, we focus on individuals' primary employment. Using a similar procedure with RAMS data, Nordström Skans, Edin, and Holmlund (2008) found that this gives rise to a computed wage distribution that is close to the direct measure of the wage distribution taken from the 3 percent random sample in the LINDA database (see Edin and Fredriksson, 2000).

${ }^{26}$ We use a definition of homogenous local labor markets constructed by Statistics Sweden using commuting patterns. We use the 1993 definition which divides Sweden into 109 areas.
} 
contains the number of employees in period $t-1$ (November last year) for each cell of firm $f$ which operates in local labor market $j .{ }^{27}$

Empirically, we start by estimating the Mincer equation outlined in (10) for each local labor market and year. Thus, we estimate 1,417 (13 years by 109 local labor markets) Mincer equations. The number of full-time primary employments in the private sector covering November ranges from 1, 499, 285 employed individuals in the recession year 1993 to 2, 056, 509 employed individuals in 2001. For each year and local labor market we regress the log observed monthly wages on age, age squared, age cubed, sex, two-digit sector-code (NACE) dummies, two-digit education-level (ISCED 97) dummies, threedigit education-field (ISCED 97) dummies, immigrant-status dummies for seven different regions of origin and, finally, for missing education information, we also create interaction dummies for this category with immigrant status by origin.

Then, we project period $t$ wage sums for each firm by using the characteristics of the employees working in the firm in period $t-1$ (i.e. November last year) and the characteristic-specific wage predictions from the $(j, t)$ Mincer equation. Since no firm in the sample employs more than 3.2 percent of the total number of workers within a specific education cell, defined by two-digit level by three-digit field code, in any local labor market at any point in time, monopsony power in the local labor market does not seem to be a concern. Finally, as presented in more detail in Appendix B, we do seem to get the projected wage sums right. Moreover, the projected marginal cost measure (11) is strongly correlated with the unit labor cost, even when we control for sector-specific time effects and firm-specific fixed effects. Thus, there is a variation in the dimensions needed to identify the firm-level effects of marginal cost on prices (once more, see Appendix B for details).

\subsection{Taking the Models to the Data}

In this section, we discuss how to take the models to the data, combining the above discussion with other identification issues we need to consider.

Empirical Considerations for the Frictionless Model and the Maćkowiak and Wiederholt (2009) Model

\footnotetext{
${ }^{27}$ Note also that we dropped the $1 / \alpha$ term, as compared to $(9)$, since this will be picked up by fixed effects.
} 
To test the frictionless hypothesis, we introduce a free parameter $\lambda$ on the marginal cost term in equation (6), which we expect to equal unity in the absence of any frictions, as well as adding an error term to this equation. As discussed above, since we expect the error term in this regression to be correlated with marginal cost, we use the projected marginal cost (current and lagged) as well as the (lagged) unit labor cost as instruments. Thus, we rely on the following moments

$$
E_{t}\left\{\left(\ln P_{g, t}-\gamma_{g, 0}-\lambda \ln M C_{f, t}\right) \mathbb{Z}_{F M, t}\right\}=0
$$

to estimate the $\lambda$, where $Z_{F M, t}$ denotes the instrument set discussed above. Finally, we also include sector-specific time dummies. Given this, estimates of $\lambda$ also provide a test of the prediction from the Maćkowiak and Wiederholt (2009) Rational Inattention Model that firms will react strongly to idiosyncratic conditions. Here, we interpret this prediction as $\lambda$ being close to unity.

\section{Empirical Considerations for the Calvo (1983) Model}

To take the Calvo (1983) model (7) to the data, we need to handle a series of complications. First, (7) includes an infinite sum of current and future marginal cost. However, the terms in this sum fall to zero. Using the quarterly aggregate estimate of $\theta=0.84$ reported by Adolfson, Laséen, Lindé, and Villani (2008) for domestic Swedish firms and likewise assuming that $\beta=0.99$, we will expect a coefficient on current marginal cost of 0.52 in annual data. ${ }^{28}$ Similarly, the coefficient for $E_{t} \ln M C_{f, t, t+1}$ will be 0.25 , and for $E_{t} \ln M C_{f, t, t+2}$ we will have a coefficient of 0.12 . Given that the coefficients will be falling fairly rapidly towards zero, we truncate the sum in (7) to $k \in\{0,1\}$ in our empirical application. We also need to condition the regression on firms that actually change their price since (7) expresses the optimal reset price. Then, we rely on observations where $d \ln P_{g, t} \neq 0$ by excluding observations of very small price changes (below \pm 0.5 percent) from the estimation sample. ${ }^{29}$ Moreover, we need to handle the expectations operator in the $k=1$ term in (7). Here, we follow Galí and Gertler (1999) and Galí, Gertler, and

\footnotetext{
${ }^{28}$ The coefficient on current marginal cost is calculated as $(1-(0.84 \cdot 0.99)) \cdot(1+(0.84 \cdot 0.99)+(0.84$. $\left.0.99)^{2}+(0.84 \cdot 0.99)^{3}\right)=0.52$. Thus, annual data are considered as mid-year realizations. Note, though, that it is not obvious how to assign quarterly coefficients to annual coefficients.

${ }^{29}$ Remember that since the prices are calculated from reported values and volumes of sold goods, there might be small rounding errors leading to too few zero observations in the data.
} 
López-Salido (2001) and define $Z_{C M, t-n}$ as a matrix of variables observed in time $t-n$ and note that under rational expectations, equation (7) and the above assumptions define a set of orthogonality conditions ${ }^{30}$

$$
E_{t}\left\{\left(\ln P_{g, t}-\gamma_{g, 0}-\gamma_{1} \ln M C_{f, t}-\gamma_{2} \ln M C_{f, t+1}\right) \mathbb{Z}_{C M, t-n}\right\}=0
$$

Using the orthogonality conditions (13), we can estimate the model using generalized methods of moments (GMM). However, we also need to recognize that the instruments need to be orthogonal to any contemporaneous markup disturbance. Thus, we use lagged information as instruments. Moreover, since the panel is short, we will use an Arellano and Bond (1991) GMM estimator with a dynamic instrument matrix to save on data. The Arellano and Bond (1991) estimator involves differencing the levels equation and instrumenting with lagged levels. ${ }^{31}$ This, in turn, implies that we introduce an MA structure in the errors which need to be considered when deciding on which lags to include. However, the starting point of the instrument set will be determined after formal testing of the time dependence in the error terms. The truncation of the sum in $(7)$ to $k \in\{0,1\}$ also implies that there will be components in the error term that are correlated with all lagged information as far as the expectation of marginal cost in period $t+2$ and beyond is correlated with the lagged information included in the instrument set. In section 5 below, we take steps to address this potential problem. Finally, we also include sector-specific time dummies in (13). Note that by including these dummies we wipe out all aggregate and sectoral variation and, thus, remove any effects of trend inflation or relative-price adjustment between sectors within the sample. ${ }^{32}$

\section{Empirical Considerations for the Mankiw and Reis (2002) Model}

In the Mankiw and Reis (2002) Model, price is set as stated in (8). Then, once more,

\footnotetext{
${ }^{30}$ Note that in order to save on data, we use the unconditional future outcome of marginal cost in the empirical implementation. This should not be problematic if the marginal cost curve is fairly flat, as indicated by the results presented below.

${ }^{31}$ Note that when estimating the model in differenced form, we actually need to estimate the model on observations where the price changed both today and yesterday in order to identify $\gamma_{1}$ and $\gamma_{2}$. When doing this, we assume that the first observation in each price spell is a changed price in order to save on data. Note that the data implies that about 86 percent of the prices are changed each period. Moreover, for the initial price observation, it is only unobserved previous spells that can contain unchanged prices, not new spells due to the introduction of new products (where the price is reset by definition) or spells split by the data cleaning procedure described in Appendix A.

${ }^{32}$ This is thus a micro-data version of a prefiltering of the data, which is often used in applied macroeconomics.
} 
forming moment conditions we get

$$
E_{t}\left\{\left(\ln P_{g, t}-\gamma_{g, 0}-\gamma_{1} \ln M C_{f, t}\right) \mathbb{Z}_{M R M, t-h}\right\}=0
$$

where $\gamma_{1}$ is expected to equal unity. Here, the instruments need to be lagged back sufficiently far to ensure that all cohorts of firms should have been able to update their information sets. Thus, our strategy is to identify $\gamma_{1}$ by using variation in marginal cost that any information cohort of firms should have been able to predict, i.e. by setting an appropriate value on $h$ in (14). Using the calibration of Mankiw and Reis (2002) where the quarterly probability of firms to update their information set is set to 0.25 , we expect the fraction of uninformed to be about $0.32\left(=0.75^{4}\right)$ after one year and 0.03 after three years. ${ }^{33,34}$ Once more, we will use the Arellano and Bond (1991) GMM estimator to save on data. ${ }^{35}$ Finally, we include sector-specific time dummies.

\section{Results}

\section{The Frictionless Model / The Maćkowiak and Wiederholt (2009) Model}

We start by testing if there are any frictions at all in firm-level price setting (at least measurable at the annual frequency). We include dummies for the interaction of time and two-digit sector code. Thus, the specification looks at the response of relative prices due to idiosyncratic movements in marginal cost. This also ensures that we compare firms acting in similar product markets, but which experience different marginal cost movements since they, e.g., act on different factor markets (i.e., acting on different local labor markets and/or employing a different skill structure). In the first column of table 1, we present OLS results, ignoring any endogeneity problems, indicating a statistically significant (at the five-percent level) price elasticity of marginal cost change onto prices of 0.27. Although significantly larger than zero, the point estimate is also well below,

\footnotetext{
${ }^{33}$ Here we consider annual observations to be mid-year observations.

${ }^{34}$ The value of 0.25 , i.e. the quarterly probability of firms to update their information set, is also in line with the empirical evidence in Mankiw, Reis, and Wolfers (2003).

${ }^{35}$ Since this involves differencing the model, it actually implies that with the fourth lag in the instrument set, there are three periods that have passed between the information set we use and the lag of marginal cost (included in the difference) we instrument.
} 
Table 1: Flexible Price Model / Maćkowiak and Wiederholt Model

\begin{tabular}{lccc}
\hline \hline Dependent Variable: $\ln P_{g, t}$ & $\mathrm{~F} / \mathrm{M} \& \mathrm{~W}$ & $\mathrm{~F} / \mathrm{M} \& \mathrm{~W}$ & $\mathrm{~F} / \mathrm{M} \& \mathrm{~W}$ \\
\hline $\ln M C_{f, t}$ & 0.265 & 0.320 & 0.334 \\
& $(0.019)^{* *}$ & $(0.061)^{* *}$ & $(0.055)^{* *}$ \\
\hline Estimator & $\mathrm{OLS}$ & $\mathrm{IV}$ & $\mathrm{IV}$ \\
Instrument Set: & & $j=\{0,1\}$ & $j=\{0,1\}$ \\
$\ln \overline{M C}_{f, t-j}$ & & & $j=\{1,2\}$ \\
$\ln M C_{f, t-j}$ & & 0.19 & 0.45 \\
\hline Hansen J p-value) & 17,282 & 14,067 & 14,067 \\
Number of Observations & 3,510 & 3,144 & 3,144 \\
Number of Product/Firm ID:s & & & \\
\hline \hline
\end{tabular}

Superscript $*$ and $* *$ denote significantly different from zero at the five/one-percent level. Standard-errors clustered on products inside parenthesis. All regressions include time interacted with two-digit sector-code dummies and product fixed effects. Hansen J denotes the p-value of the joint test of model specification and instrument validity. IV-estimates computed using the Stata module XTIVREG2; see Schaffer (2007).

and statistically different from, unity. ${ }^{36}$ Using the current and lagged values of the projected marginal cost as instruments, we see in the second column of table 1 that the point estimate increases slightly to 0.32 , but still remains well below unity. Thus, using IV methods does not lead to any dramatic changes in the results. Although the standard error triples, the result is still significantly larger than zero, and smaller than one, at the five-percent level. One interpretation of this finding is that the firm's marginal cost curve is not very steep, thus only leading to a mild bias when relying on OLS. ${ }^{37}$ Note also that the IV-approach ensures that possible classical measurement errors in the explanatory variable (or the instrument) is not a source of bias as long as potential errors are uncorrelated between the instrument and the endogenous variable. Thus, in the presence of measurement errors the change in the estimate when using instruments provides an upper bound on the effect of the slope of the firm's marginal cost curve on the estimate. Moreover, as shown in the third column of table 1, adding the first and the second lag of unit labor cost to the instrument set only marginally changes the point estimate to 0.33 and slightly lowers the standard error. ${ }^{38}$

\footnotetext{
${ }^{36}$ Since some firms in our sample sell several different products simultaneously, a possible concern is that the error terms for individual products within those firms may be correlated. This would then affect the inference. However, it is not obvious in which dimension to cluster the standard errors. In the main results, we have clustered on each product within a firm (allowing for an arbitrary error-term pattern within observations for a product), but this issue is addressed in more detail in Appendix C.

${ }^{37}$ Since the bias in the OLS estimate appears to be negative, the results suggest that marginal cost is negatively correlated to the markup shock, thus implying that the firm's marginal cost curve is (mildly) upward sloping.

${ }^{38}$ As can also be seen in table 1 , the Hansen test of the overidentifying restrictions cannot reject the
} 
All in all, we can reject the null that marginal cost changes are fully passed into prices within the year. Moreover, this finding is not readily consistent with the Maćkowiak and Wiederholt (2009) version of the Rational Inattention Model where firms react strongly and immediately to idiosyncratic factors. ${ }^{39}$

\section{The Calvo (1983) Model / The Mankiw and Reis (2002) Model}

Next, we turn to estimate the Calvo (1983) model (13) above. As explained above, we use the Arellano and Bond (1991) GMM estimator with a dynamic instrument set that grows over time as further lags of the instruments become available. Relying on the Arellano and Bond (1991) autocorrelation test of the differenced residual, as well as the Hansen test of the overidentifying restrictions, we start the instrument set at the second lag of the projected marginal cost and at the third lag of marginal cost. To avoid overfitting, we collapse the instrument set. That is, we impose the restriction that the relationships in the "first stage" are the same across all time periods (see e.g. Roodman, 2006, for a discussion). Then we add lags until the estimates are stabilized. Using this procedure, we find that we can cut the instrument set at the ninth lag. However, the results are robust to including the full available history of instruments. Moreover, as discussed above, we only include observations where the prices actually change.

The first-step GMM results are presented in table 2. As can be seen in the first column of table 2, both the current and the expected marginal cost enter significantly at the five-percent level. Interestingly, the point estimates, 0.44 for current marginal cost and 0.28 for expected marginal cost, are close to what would be expected when combining the structural equation of the optimal price in the Calvo model with the estimate of the aggregate quarterly probability of no price adjustment $(\theta)$ of 0.84 from Adolfson, Laséen, Lindé, and Villani (2008). In that case, we would expect coefficients of 0.52 and 0.25 , respectively, for the current and the expected marginal cost. Moreover, using the US (Euro Area) estimate for $\theta$ of 0.87 (0.90) presented by Smets and Wouters (2005), we would expect coefficients of $0.45(0.37)$ and $0.25(0.23)$, respectively, for the current and

null of a correctly specified model and valid instruments for any of the two IV specifications.

${ }^{39}$ One potential concern is that the Maćkowiak and Wiederholt (2009) Model is calibrated for US data. However, the impulse-responses of output and inflation to a monetary-policy shock estimated by Adolfson, Laséen, Lindé, and Villani (2008) using Swedish data are in line with the "conventional wisdom" for the US of a maximum impact after one to one year and a half, thus pointing towards a considerable similarity between the two economies. Moreover, figure 1 gives witness to a substantial volatility at the micro level, as is also recorded for the US. 
Table 2: Calvo Model / Mankiw and Reis Model

\begin{tabular}{|c|c|c|c|c|}
\hline Dependent Variable: $\ln P_{g, t}$ & Calvo & Calvo & M\&R & M\&R \\
\hline $\ln M C_{f, t}$ & $\begin{array}{l}0.442 \\
(0.154)^{* *}\end{array}$ & $\begin{array}{l}0.562 \\
(0.165)^{* *}\end{array}$ & $\begin{array}{c}0.327 \\
(0.132)^{*}\end{array}$ & $\begin{array}{c}0.296 \\
(0.130)^{*}\end{array}$ \\
\hline$E_{t} \ln M C_{f, t+1}$ & $\begin{array}{c}0.279 \\
(0.133)^{*}\end{array}$ & $\begin{array}{l}0.364 \\
(0.154)^{*}\end{array}$ & & \\
\hline $\begin{array}{l}\text { Estimator } \\
\text { Only Firms Adjusting Price } \\
\text { Instrument Set (Collapsed): }\end{array}$ & $\begin{array}{c}\text { DIFF GMM } \\
Y e s\end{array}$ & $\begin{array}{c}\text { DIFF GMM } \\
Y e s\end{array}$ & $\begin{array}{c}\text { DIFF GMM } \\
N_{O}\end{array}$ & $\begin{array}{c}\text { DIFF GMM } \\
N_{O}\end{array}$ \\
\hline $\begin{array}{l}\ln \widehat{M C}_{f, t-j} \\
\ln M C_{f, t-j}\end{array}$ & $\begin{array}{l}j=\{2, ., 9\} \\
j=\{3, ., 9\}\end{array}$ & $\begin{array}{l}j=\{3, . .9\} \\
j=\{4, ., 9\}\end{array}$ & $\begin{array}{l}j=\{3, . .9\} \\
j=\{3, ., 9\}\end{array}$ & $\begin{array}{l}j=\{4, ., 9\} \\
j=\{4, ., 9\}\end{array}$ \\
\hline $\mathrm{AR}(2)(p$-value $)$ & 0.00 & 0.00 & 0.00 & 0.00 \\
\hline $\operatorname{AR}(3)(p$-value $)$ & 0.07 & 0.06 & 0.05 & 0.05 \\
\hline $\mathrm{AR}(4)(p$-value $)$ & 0.28 & 0.20 & 0.66 & 0.68 \\
\hline Hansen J (p-value) & 1.00 & 1.00 & 1.00 & 0.00 \\
\hline Number of Observations & 10,141 & 10,141 & 13,772 & 13,772 \\
\hline Number of Firms/Products & 3,106 & 3,106 & 3,510 & 3,510 \\
\hline
\end{tabular}

Superscript ${ }^{*}$ and ${ }^{* *}$ denote significantly different from zero at the five/one-percent level. All regressions include time interacted with two-digit sector-code dummies and product fixed effects. The estimation is performed using the Arellano and Bond (1991) generalized method of a moments difference estimator computed by the Stata module XTABOND2; see Roodman (2006). One-step coefficents with robust standard errors in parenthesis (clustered on products). $\mathrm{AR}(\mathrm{x})$ denotes the $\mathrm{p}$-value for the test of $\mathrm{x}$-order autocorrelation in the differenced residuals. Hansen $\mathrm{J}$ denotes the p-value of the joint test of model specification and instrument validity from the second-step estimator.

the expected marginal cost. In fact, the joint hypothesis of equality between the micro estimates and the expected values, derived from any of the macro estimates mentioned above, cannot be rejected in a formal test on any reasonable level of significance. ${ }^{40} \mathrm{We}$ can also compare the micro estimates for the Calvo model parameters presented in table 2 to what is implied directly from the data at hand, as well as from micro data underlying producer-price index calculations. To this end, we first calculate the implied quarterly Calvo probability, $\theta$, of being stuck with the old price directly from the share of unchanged prices in the data. Note that to observe an unchanged price, we need the price to be fixed for eight quarters since the price data are annual averages. ${ }^{41}$ Defining the share of unchanged prices as the share of price changes within the \pm 0.5 percent interval then implies a Calvo probability of 0.78 and expected coefficients of 0.64 and 0.23 for $\ln M C_{f, t}$ and $E_{t} \ln M C_{f, t+1}$, respectively. ${ }^{42}$ Thus, this crude approach gives rise to expected values well within the range of the results from our econometric approach above and, once

\footnotetext{
${ }^{40}$ This is also the case if we use the estimates from the second column of table 2 discussed below.

${ }^{41}$ Any within-year changes during one of the two years make the annual averages differ between years.

${ }^{42} \theta$ is given as the solution to $\theta^{8}=0.136$.
} 
more, the joint hypothesis of equal parameters cannot be rejected (using any of the first two columns of table 2). Second, we use the median monthly frequency of price changes of 0.108 reported by Nakamura and Steinsson (2008) for U.S. micro producerprice data to compute expected values for the Calvo model. ${ }^{43}$ This implies a quarterly of Calvo probability of 0.71 and gives rise to expected coefficients of 0.76 and 0.18 for $\ln M C_{f, t}$ and $E_{t} \ln M C_{f, t+1}$, respectively. For comparison, we find a monthly price-change frequency of 0.08 (again using the spike in the data). Thus, the Nakamura and Steinsson (2008) estimate implies more frequent price changes than the data at hand. However, it is important to note that Nakamura and Steinsson (2008) report a substantial heterogeneity across sectors in the monthly frequency of price changes (from 0.013 to 0.875 ) and, in the light of this dispersion, the finding here does not stand out as very low. Moreover, the $\mathrm{p}$-value for the joint hypothesis of equal parameters between the micro estimates reported in the first column of table 2 and the expected values calculated from Nakamura and Steinsson (2008) equal 0.06 (0.14, using the second column of table 2). ${ }^{44}$ All in all, the estimation results for the Calvo model seem to be reasonable as compared to what is expected from both macro and micro studies.

To investigate if the truncation bias, discussed above, is a severe problem, we take two different steps. First, we lag the instrument set one additional period backwards in time. This further strengthens the results yielding a coefficient on current marginal cost of 0.56 and a coefficient on expected marginal cost of 0.36 with only slightly higher standard errors as compared to the baseline results. Thus, if anything, the truncation bias seems to work against finding significant results in the baseline case. Second, we try to include $E_{t} \ln M C_{f, t+2}$ in (13). Since there is a problem with passing the $\operatorname{AR}(3)$ test we then use the same instrument set as in the previous exercise. We still find positive and significant estimates for $\ln M C_{f, t}$ and $E_{t} \ln M C_{f, t+1}$ at the five-percent level; although the estimates for $E_{t} \ln M C_{f, t+2}$ are also positive, it is not significant on the five-percent level. All in all,

\footnotetext{
${ }^{43}$ To our knowledge, no similar study has been performed on the Swedish micro data underlying producer-price index calculations.

${ }^{44}$ Vermeulen et. al. (2007) also report a substantial degree of heterogeneity across sectors when studying price-setting behavior on monthly micro data on producer prices for six European countries. Interestingly, the mode of the monthly price-change distribution reported by Vermeulen et. al. (2007) (0.09) is close to what is reported above for the average monthly price-change frequency (0.08) although, once more, the distribution shows outliers of high frequency of price changes. Using the significantly higher average weighted monthly frequency of price changes of 0.21 reported by Vermeulen et. al. (2007) leads to a rejection of the null of the joint hypothesis of equal parameters at the five-percent level (using any of the first two columns of table 2).
} 
the truncation of the sum in the Calvo model does not seem to be a problem empirically.

Note also that these estimates imply a substantial pass-through of marginal cost onto the price. The estimates imply a price elasticity of 0.72 (with a s.e. of 0.22 ) with respect to a permanent increase in marginal cost $(0.93$, with a s.e. of 0.25 , if we lag the instrument set one additional period). Thus, we cannot statistically reject that the coefficients sum to unity. Note also that since we estimate a truncated version of the Calvo model, we expect the point estimates to sum to a value somewhat below unity. ${ }^{45}$ Thus, the point estimates are well in line what we expect from the Calvo model in this respect.

Next, we turn to the Sticky Information Model of Mankiw and Reis (2002). The idea here is to identify price effects of marginal cost movements that could have been projected by the bulk of all information vintages of firms. In the case where all firms could have projected this variation, we expect a coefficient of unity since it is information that is sticky, not prices. However, as can be seen in the third and fourth columns of table 2, the coefficient on marginal cost is almost unchanged as we lag the instrument set further back in time (c.f. also the estimates presented in table 1). We would expect it to tend towards unity in a Mankiw and Reis (2002) world since an increasing share of firms would have the information in their information set and would thus be able to react to this variation in marginal cost when making their price plans. Note that given the probability of the information set being updated in each quarter of 0.25 and considering annual data as mid-year to mid-year observations, the share of firms not having the period $t-3$ outcome of their marginal cost in their information set is only about three percent. ${ }^{46}$ Note also that through the columns of table 2 , there is barely a change in the standard errors for the coefficient on $\ln M C_{f, t}$, thus indicating that weak instruments is not the cause of our finding. ${ }^{47}$ All in all, the results do not support the Mankiw and Reis (2002) notion that information, rather than prices, is sticky.

\footnotetext{
${ }^{45}$ See the discussion of the Calvo model in 4.3 .

${ }^{46}$ When we start the instrument set at $t-4$, the relevant time span for calculating the share of uninformed is three years, since the model is differenced when estimated.

${ }^{47}$ The Hansen test of overidentifying restrictions rejects the null of valid instruments and a correctly specified model in column four of table 2. However, we do not read too much into this result since it is not consistent throughout specifications (c.f. also table 1). Moreover, the models subjected to the data in this paper are very stylized and we can be pretty certain that none of them represent the true data generating model. The question at hand is rather if they represent reasonable approximations.
} 


\section{Concluding Discussion}

We use very detailed Swedish micro data on product producer prices, linked to a rich matched employer-employee data set containing information on the firms that set these prices to test the empirical relevance of different proposed microfoundations for pricing used in competing business cycle models. We construct a measure of marginal cost based on unit labor cost which is consistent with the bulk of macro models in the literature and test the hypothesis of no frictions in the pricing decision. Since marginal cost is unlikely to be exogenous, we take an IV/GMM approach in the empirical work. Beside internal instruments, i.e. lags, we exploit that we have access to detailed information on all employees within each firm in the private sector. Relying on this information, we construct an instrument based on the market valuation of the (lagged) skill composition of the firm normalized by the lagged production level.

We find an instantaneous price elasticity with respect to marginal cost of about 0.3 , i.e. well below the unit elasticity predicted by a frictionless model. Since we include sector-specific time dummies in all regressions, our model studies relative price reactions to idiosyncratic marginal cost changes. Our findings thus speak against the Maćkowiak and Wiederholt (2009) version of the Rational Inattention Model, which predicts that firms react strongly and immediately to idiosyncratic movements in marginal cost.

However, the lack of a full pass-through of marginal cost movements is consistent with nominal frictions such as staggered contracting and we proceed by estimating the Calvo (1983) pricing equation, which is the key underlying pricing relationship in the standard workhorse macro model. This relationship relates the price set by a firm (when changing the price) today to a discounted sum of today's and future marginal cost. Relying on IV/GMM methods and the instruments discussed above, we find that the data do support that firms consider both current, as well as, future expected marginal cost when setting prices. Moreover, the estimated parameters are reasonable as compared to what is expected from both macro and micro studies. Also, as predicted by the Calvo (1983) model, the sum of coefficients is not significantly different from unity.

Another hypothesis that is consistent with not finding a full pass-through of observed marginal cost onto prices is that firms are not fully aware of their current marginal cost except when drawn to update their information set. That is, information is sticky as in the Mankiw and Reis (2002) Model. However, once more relying on IV/GMM methods, we 
do not find that firms react strongly to marginal cost changes that could be predicted by the vast majority of information vintages of firms as predicted by the Sticky Information Model. In fact, lagging the instruments set backwards does not affect the point estimates of the pass-through of marginal cost onto the price to any noticeable extent. Thus, the data do not support the notion that information is sticky in the Mankiw and Reis (2002) sense.

In this paper, we have chosen not to venture into evaluating the relative performance of menu-cost models. This would entail estimating probability models of the price change decisions. However, given that we rely on annual data, there is only a moderate share of observations with unchanged prices. Thus, the data set at hand is not very well suited to this type of analysis. However, it is worth pointing out that the Calvo model is not the only model in the literature that can explain infrequent price changes. As better suited data may become available further down the road, it would be interesting to also evaluate this type of models, perhaps in conjunction with information imperfections as suggested by Maćkowiak and Wiederholt (2009). 


\section{References}

Adolfson, M., S. Laséen, J. Lindé, and M. Villani (2008): "Evaluating An Estimated New Keynesian Small Open Economy Model," Journal of Economic Dynamics and Control, 32, 2690-2721.

Álvarez, L. J., E. Dhyne, M. M. Hoeberichts, C. Kwapil, H. Le Bihan, P. Lunnemann, F. Martins, R. Sabbatini, H. Stahl, P. Vermeulen, and J. Vilmunen (2006): "Sticky Prices in the Euro Area: A Summary of New Micro Evidence," Journal of the European Economic Association, 4, 575-584.

Apel, M., R. Friberg, and K. Hallsten (2005): "Microfoundations of Macroeconomic Price Adjustment: Survey Evidence from Swedish Firms," Journal of Money, Credit and Banking, 37, 313-338.

Arellano, M., And S. Bond (1991): "Some Tests of Specifications for Panel Data: Monte Carlo Evidence and Application to Employment Equations," Review of Economic Studies, 58, 277-297.

Bils, M. (1987): "The Cyclical Behavior of Marginal Cost and Price," American Economic Review, 77, 838-855.

Bils, M., And P. Klenow (2004): "Some Evidence on the Importance of Sticky Prices," Journal of Political Economy, 112, 947-985.

Blinder, A., E. Canetti, D. Lebow, and J. Rudd (1998): Asking About Prices: A New Approach to Understand Price Stickiness. Russel Sage Foundation, New York.

Boivin, J., M. Giannoni, And I. Mihov (2009): "Sticky Prices and Monetary Policy: Evidence From Disaggregated U.S. Data," American Economic Review, 99, 350384.

Buckle, R., and J. Carlson (2000): "Inflation and Assymetric Price Adjustment," Review of Economics and Statistics, 82, 157-160.

Calvo, G. (1983): "Staggered Prices in a Utility-Maximizing Framework," Journal of Monetary Economics, 12, 383-398.

Christiano, L., M. Eichenbaum, and C. Evans (1999): "Monetary Policy Shocks: What Have we Learned and to What End?," in Handbook of Macroeconomics, ed. by J. Taylor, and M. Woodford, vol. 1B, pp. 65-148, Amsterdam. Elsevier. 
(2005): "Nominal Rigidities and the Dynamic Effects of a Shock to Monetary Policy," Journal of Political Economy, 113, 1-45.

Coibion, O. (2007): "Testing the Sticky Information Phillips Curve," forthcoming, Review of Economics and Statistics.

Davis, M., And J. Hamilton (2004): "Why are Prices Sticky, The Dynamics of Wholsale Gasoline Prices," Journal of Money Credit and Banking, 36, 17-37.

Dhyne, E., L. J. Álvarez, H. Le Bihan, G. Veronese, D. Dias, J. Hoffmann, N. Jonker, P. Lunnemann, F. Rumler, and J. Vilmunen (2006): "Price Setting in the Euro Area and the United States: Some Facts From Individual Consumer Price Data," Journal of Economic Perspectives, 20, 171-192.

Druant, M., S. Fabiani, G. Kezdi, A. Lamo, F. Martins, and R. Sabbatini (2008): "How are Firm's Wages and Priced Linked: Survey Evidence in Europe," Paper presented at the "Wage Dynamics in Europe: Findings from the Wage Dynamics Network" conference, European Central Bank, 24-25 June, 2008.

Edin, P.-A., And P. Fredriksson (2000): "LINDA - Longitudinal INdividual DAta for Sweden," Working Paper 2000:19, Department of Economics, Uppsala University.

Eichenbaum, M., N. Jaimovic, and S. Rebelo (2008): "Reference Prices and Nominal Rigidities," NBER WP 13829.

Fabiani, S., M. Druant, I. Hernando, C. Kwapil, B. Landau, C. Loupias, F. Martins, T. Mathä, R. Sabbatini, H. Stahl, and A. Stokman (2006): "What Firms' Surveys Tell Us About Price-Setting Behaviour In The Euro Area," International Journal of Central Banking, 2, 3-48.

Fischer, S. (1997): "Long Term Contracts, Rational Expectations, and the Optimal Money Supply Rule," Journal of Political Economy, 85, 163-190.

Galí, J., and M. Gertler (1999): "Inflation Dynamics: A Structural Econometric Analysis," Journal of Monetary Economics, 44, 195-222.

Galí, J., M. Gertler, And D. López-Salido (2001): "European Inflation Dynamics," European Economic Review, 45, 1237-1270.

Kleibegen, F., and R. PaAp (2006): "Generalized Reduced Rank Tests Using the Singular Value Decomposition," Journal of Econometrics, 133, 97-126. 
Klenow, P., And O. Kryvtsov (2008): "State-Dependent or Time Dependent Pricing: Does it Matter for Recent U.S. Inflation," Quarterly Journal of Economics, 123, 863-904.

Levy, D., S. Dutta, and M. Bergen (2002): "Heterogeneity in Price Rigidity: Evidence from a Case Study Using Microlevel Data," Journal of Money, Credit and Banking, 34, 197-220.

LindÉ, J. (2005): "Estimating New-Keynesian Phillips Curves: A Full Information Maximum Likelihood Approach," Journal of Monetary Economics, 52, 1135-1149.

Loupias, C., and P. Sevestre (2008): "Cost, Demand and Producer Price Changes," mimeo, Université de Paris I - Panthéon Sorbonne.

LucAs, R. E. (1972): "Expectation and the Neutrality of Money," Journal of Economic Theory, 4, 326-334.

Lundin, M., N. Gottfries, C. Bucht, and T. Lindström (2007): "Price and Investment Dynamics: Theory and Plant Level Data," forthcoming, Journal of Money, Credit and Banking.

Maćkowiak, B., E. Moench, and M. Wiederholt (2008): "Sectoral Price Data and Models of Price Setting," forthcoming, Journal of Monetary Economics.

Maćkowiak, B., and M. Wiederholt (2009): "Optimal Sticky Prices under Rational Inattention," American Economic Review, 99, 769-803.

Mankiw, G. N., And R. Reis (2002): "Sticky Information Versus Sticky Prices: A Proposal to Replace the New Keynesian Phillips Curve," Quarterly Journal of Economics, 117, 1295-1328.

Mankiw, G. N., R. Reis, and J. Wolfers (2003): "Disagreement About Inflation Expectations," in NBER Macroeconomics Annual, ed. by M. Gertler, and K. Rogoff, pp. 209-248. MIT Press.

Nakamura, E., and J. Steinsson (2008): "Five Facts About Prices: A Reevaluation of Menu Cost Models," Quarterly Journal of Economics, 123, 1415-1464.

Nordström Skans, O., P.-A. Edin, And B. Holmlund (2008): "Wage Dispersion Between and Within Plants: Sweden 1985-2000," in Wage Structure, Raises and 
Mobility: International Comparisons of the Structure of Wages Within and Across Firms, ed. by E. Lazear, and K. Shaw. University of Chicago Press, Chicago, IL. Peltzman, S. (2000): "Prices Rise Faster than They Fall," Journal of Political Economy, 108, 466-502.

Phelps, E. (1970): "Introduction: The Microeconomics in Employment and Inflation Theory," in Microeconomic Foundations of Employment and Inflation Theory, ed. by E. Phelps et al. Norton, New York.

Reis, R. (2008): "Optimal Monetary Policy Rules in an Estimated Sticky-Information Model," forthcoming, American Economic Journal: Macroeconomics.

Roodman, D. (2006): "How to Do XTABOND2: An introduction to "Difference" and "System" GMM in Stata," Working Paper Number 103, Center for Global Development.

Rotemberg, J., and M. Woodford (1999): "The Cyclical Behavior of Prices and Costs," in Handbook of Macroeconomics, ed. by J. Taylor, and M. Woodford, vol. 1B, chap. 16, pp. 1051-1135. Elsevier Science B.V., Amsterdam.

Sbordone, A. (2002): "Prices and Unit Labor Costs: A New Test of Price Stickiness," Journal of Monetary Economics, 49, 265-292.

Schaffer, M. (2007): "XTIVREG2: Stata Module to Perform Extended IV/2SLS, GMM and AC/HAC, LIML and K-Class Regression for Panel Data Models.," available at http://ideas.repec.org/c/boc/bocode/s456501.html.

Sims, C. (1998): "Stickiness," Carnegie-Rochester Conference Series on Public Policy, 49, 317-356.

(2003): "Implications of Rational Inattention," Journal of Monetary Economics, $50,665-690$.

Smets, F., And R. Wouters (2003): “An Estimated Dynamic Stochastic General Equilibrium Model of the Euro Area," Journal of the European Economic Association, $1,1123-1175$.

(2005): "Comparing Shocks and Frictions in US and Euro Area Business Cycles: A Bayesian DSGE Approach," Journal of Applied Econometrics, 20, 161-183. 
Staiger, D., And J. H. Stock (1997): "Instrumental Variables Regression with Weak Instruments," Econometrica, 65, 557-586.

TAylor, J. (1980): “Aggregate Dynamics and Staggered Contracts," Journal of Political Economy, 88, 1-23.

Trabandt, M. (2007): "Sticky Information V.S. Sticky Prices: A Horse Race in a DSGE Framework," Sveriges Riksbank WP 209.

Vermeulen, P., D. Dias, M. Dossche, E. Gautier, I. Hernando, R. Sabbatini, and H. Stahl (2007): "Price setting in the euro area: Some stylised facts from Individual Producer Price Data and Producer Surveys," ECB Working Paper 727.

Woodford, M. (2002): "Imperfect Common Knowledge and the Effects of Monetary Policy," in Knowledge, Information, and Expectations in Modern Macroeconomics: In Honor of Edmund S. Phelps, ed. by P. Aghion, R. Frydman, J. Stiglitz, and M. Woodford. Princeton University Press, NJ.

(2003): Interest and Prices: Foundations of a Theory of Monetary Policy. Princeton University Press, Princeton, NJ. 


\section{Appendix}

\section{A Data}

The data we use are drawn from the Industri Statistiken (IS) survey for plant-level data, the Industrins Varuproduktion (IVP) survey for the 8/9-digit price data that can be linked to the producing plant and the Register Based Labor Market Statistics data base (RAMS) for data on all employees in the private sector.

The IVP survey provides plant-level information on prices and quantities for the years 1990 - 2002 at the finest (i.e. 8/9 digit) level of the Harmonized System (HS) for the years 1990 - 1995 and according to the Combined Nomenclature (CN) for the years 1996 - 2002. Although these two coding systems are identical only down to the 6-digit level, the change means that we have no overlap in the raw data at the most detailed level between 1995 and 1996. To avoid throwing away too much information, we need to merge spells across these two coding systems while minimizing the risk of creating spells of price observations for non-identical products. Thus, we take a very cautions approach by only merging price spells for products produced by firms that only produce a single product in 1995 and 1996 and whose product code is identical between 1995 and 1996 at the 6-digit level. In the left-hand panel of figure 2, we plot the raw data distributions of log price changes (for 8/9-digit unit value data) for all price changes that we can match to the firms in the IS data (including the merged price spells in 1995/1996). All in all, this comprises 18,878 observations for 2,059 unique product codes and 4,385 unique product/firm identities across 934 firms. Each bin represents a log difference of 0.01. As can be seen in the figure, there is a substantial spike for the bin centered around zero. About 13.2 percent of the price-change observations are confined within the \pm 0.5 percent interval (with 714 observations identically equal to zero, i.e. 3.8 percent). Since the raw price data involve quite a few large swings (Max/Min. in the log price change distribution is $7.08 /-7.65)$ we apply a cleaning procedure for the data used in the analysis. We are concerned about two types of errors in the price data. First, there may be measurement errors (of some magnitude) which show up as a zigzag pattern in the growth rate of the price and, second, there may be significant changes in, say, the quality of a product within a 8/9-digit product group, which will show up as a large one-period increase in 


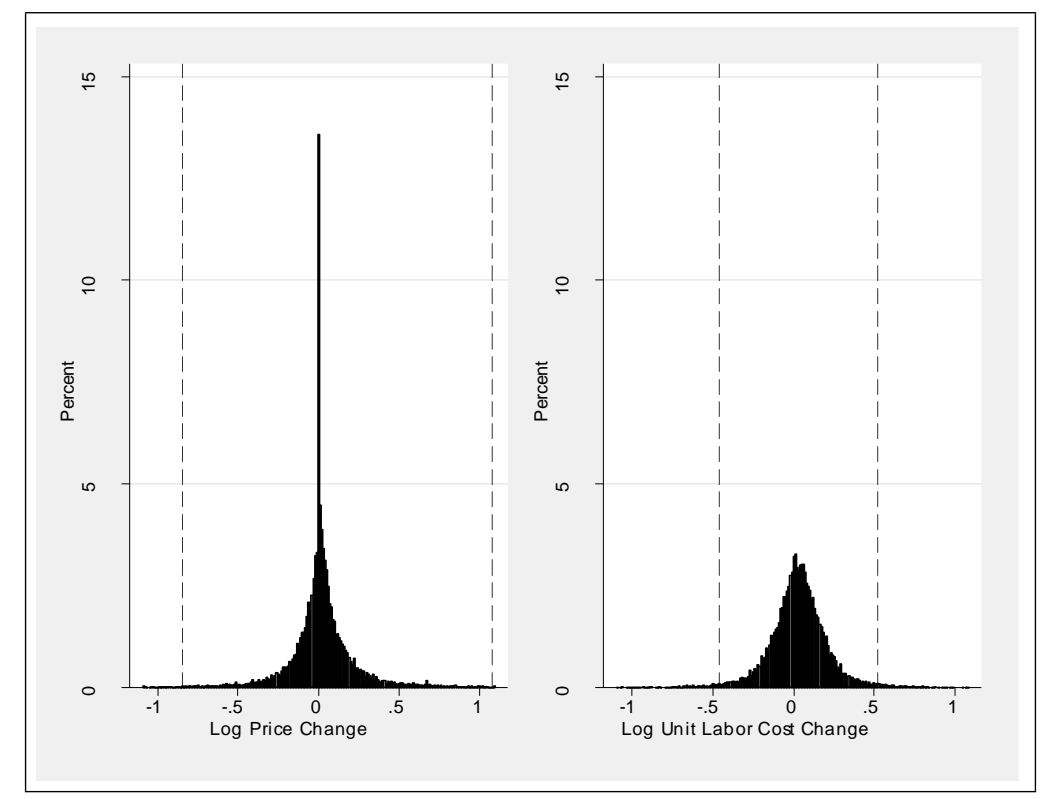

Figure 2: Histograms of raw data of log changes truncated at \pm 1.1 . The left-hand panel describes the distribution of log price changes across 18, 878 observations (for 2, 463 different products across 943 firms). The right-hand panel describes the distribution of $\log$ unit labor cost changes across 17,760 observations (for 1,480 firms). Dashed lines indicate truncation limits. Bin size 0.01 .

the difference. To remove the impact of this type of observations on the results, we split the individual price series and give them a new unique plant-price identifier whenever a large change in the growth rate appears in the data. ${ }^{48}$ We use the full distribution of log price change and determine the cut-off level as given by the 1.5 and 98.5 centiles of this distribution, depicted in the left-hand panel of figure 2. We also correct the firm-specific producer price index used to compute real output in unit labor cost by not using unitvalue data in them for these observations. Moreover, price spells with holes in them are given separate unique plant-price identifiers for each separate continuous spell.

For the data from the IS database we start out with standard data quality checking, removing obviously erroneous observations like negative sales or a zero wage bill. Moreover, after constructing the firm-level variables needed, we remove firms which are subject to large swings in unit labor cost, since we aim at capturing normal behavior and not firms in extreme circumstances. In the right-hand panel of figure 2 , we plot the log

\footnotetext{
${ }^{48}$ This implies that the effect of big zigzag patterns from a one-period measurement error in the level of the price will be removed in the estimation since both the initial (the period of the measurement error) and the following observation (and onwards) will have their own fixed effect (as well as the observations before the initial period) and whenever there is a large (permanent) drop or hike in the level of prices, we allow for different fixed effects before and after the hike/drop.
} 
changes in firm-level unit labor cost for all firms $(1,480)$ for which we can compute this measure in the IS data, in sum, 17, 760 observations. The distribution is much less spread out as compared to the price change distribution with the Max/Min at 3.52/-3.79. Similarly, as with prices, we only keep firms that have unit labor cost changes that are inside the 1.5 and the 98.5 percentile of this distribution in all years (the limits are depicted by dashed lines in the right-hand panel of figure 2).

All in all, this then leaves us with 702 firms with at least one price spell that is longer than one period. The sample of industrial firms is dominated by small to medium sized firms with an average of 65 employees. The firms are distributed across 22 twodigit sectors (NACE). The four industries with most firms represented are industry 28 (Fabricated metal products, except machinery and equipment), industry 20 (Wood and products of wood and cork), industry 15 (Food products and beverages) and industry 29 (Machinery and equipment) with altogether 422 firms (out of the 702). The four smallest sectors, industry 14 (Other mining and quarrying products), industry 23 (Coke, refined petroleum products and nuclear fuels), industry 32 (Radio, television and communication equipment and apparatus) and industry 37 (Secondary raw materials), only have one firm. ${ }^{49}$

When experimenting with the cut-off rules for prices and unit labor cost, we find the results presented in tables 1 and 2 in the main text to be robust. ${ }^{50}$

\section{B Evaluating Wage Sum Projections}

First, we plot the kernel density of the projected wage sum (obtained using RAMS data) divided by the current nominal value of the production in figure 3 and compare this to the kernel density plot of observed labor shares (computed from the IS data only) for the final sample. ${ }^{51}$ As can be seen in figure 3, the two distributions line up very well.

\footnotetext{
${ }^{49}$ Thus, when including sector-specific time dummies in the regressions, these observations will only contribute to the identification of the dummies.

${ }_{50}$ More exactly, we tried a small inward perturbation of the cut-off limits of two percentage points in log-difference space for the price change and an outward perturbation of the unit labor cost change of the same size (where the direction of the perturbation is guided by the cut-off points being more conservative for the unit labor cost change distribution than for the price change distribution), leaving us with 714 firms and 17,855 price observations in the final sample.

${ }^{51}$ We need to divide by output, otherwise the figure would mainly reflect the fact that firm size varies and this could potentially mask a weak relationship between observed and projected wage sums.
} 


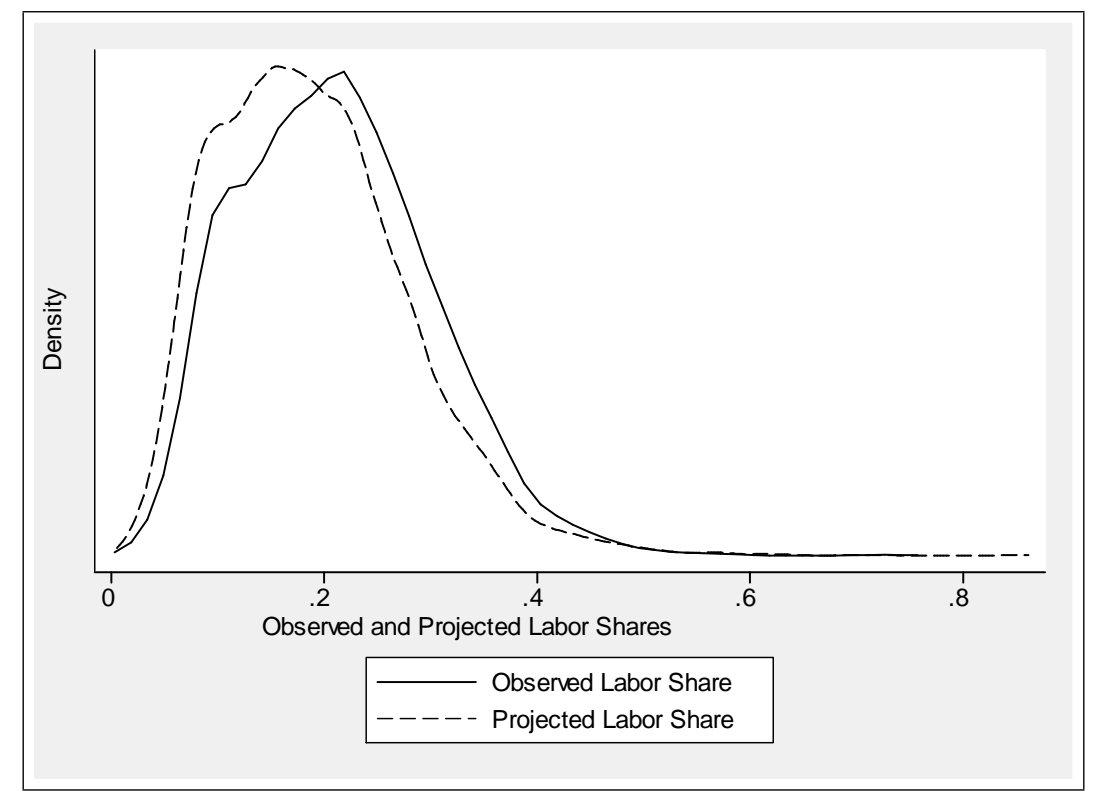

Figure 3: Kernel Density of Observed and Projected Labor Shares. Epanechnikov kernel with a bandwith of 0.013 .

It is interesting to see that the two series share almost the same mean (0.21 and 0.19 , respectively) and standard deviation (0.089 in both cases). ${ }^{52}$ Thus, we seem to get the wage sums right. Once more, note that the wage sum information is derived from two independent sources (IS and RAMS, respectively). Next, as displayed in table 3, we find

Table 3: Regressing Marginal Cost on Projected Marginal Cost

\begin{tabular}{ll}
\hline \hline Dependent Variable: $\ln M C_{f, t}$ & OLS \\
\hline $\ln \widehat{M C}_{f, t}\left(=\ln \left(\widehat{\mathbb{W}}_{j, t} \mathbb{L}_{f, t-1}^{\prime} / Y_{f, t-1}\right)\right)$ & $\begin{array}{l}0.454^{* *} \\
(0.009)\end{array}$ \\
& 8,424 \\
\hline \hline
\end{tabular}

Superscripts $*$ and $* *$ denote significantly different from zero at the five/one-percent level. The regressions include time interacted with two-digit sector-code dummies and firm fixed effects.

a very strong relationship when running a regression on observed and projected unit labor cost (i.e., the projected marginal cost), controlling for fixed effects as well as two-digit sector-specific time effects. Moreover, when including current and lagged projected unit labor cost as instruments in a fixed-effects IV regression of unit labor cost on prices, while controlling for two-digit sector-specific time dummies (c.f. column two in table 1),

\footnotetext{
${ }^{52}$ Note that this is the labor share in gross output net of payroll taxes.
} 
the null of underidentification is rejected at all significance levels (p-value equal to 0.00) relying on the Kleibergen-Paap rk LM test (see Kleibergen and Paap, 2006). Also, the first-stage F-statistic of excluded instruments equals 213.57 as opposed to the Staiger and Stock (1997) rule of thumb, deeming instruments as weak for first-stage F-values below 10. Thus, the projected unit labor cost seems to work well as an instrument for unit labor cost in terms of relevance.

\section{Intra-Firm Correlation of Errors}

Some of the firms in our sample sell several products simultaneously. ${ }^{53}$ Thus, it might be suspected that there is a correlation across error terms for individual products within a firm. If so, this cross correlation should be accounted for in the inference. One way of proceeding is to allow for arbitrary patterns of covariances between error terms within a firm by employing a sandwich estimator for the error-term variance-covariance matrix. ${ }^{54}$ This is a robust approach since it allows for any type of cross-sectional and time-series dependence but, for the same reasons, it is a blunt method which is very likely to yield too large standard errors in finite samples. As expected, standard errors arise for the coefficients presented in table 1 when using this alternative specification, but it still leaves all coefficients significant at the one-percent level. Standard-errors also increase for the Calvo and the Mankiw and Reis models. In both models, though, the p-value for the $\ln M C_{f, t}$ term is below 0.10 across all specifications (corresponding to those presented in table 2). ${ }^{55}$ Moreover, for the Calvo model, the p-values for the $E_{t} \ln M C_{f, t+1}$ term remain around 0.10 (with a sequence of p-values of $0.146,0.118$ and 0.098 as we lag the instrument set further backwards, ending at lag $4-9$ for projected marginal cost and $5-9$ for marginal cost).

\footnotetext{
${ }^{53}$ About one third of the firm/year observations consists of firms selling a single product.

${ }^{54}$ The error-term variance-covariance matrix is then defined as a block-diagonal matrix where each block is defined by a firm.

${ }^{55}$ The estimates for the Mankiw and Reis model corresponding to columns 3 and 4 in table 2 are still significantly below unity at all reasonable significance levels.
} 


\section{Earlier Working Papers:}

For a complete list of Working Papers published by Sveriges Riksbank, see www.riksbank.se

Estimation of an Adaptive Stock Market Model with Heterogeneous Agents by Henrik Amilon ........ 2005:177

Some Further Evidence on Interest-Rate Smoothing: The Role of Measurement

Errors in the Output Gap by Mikael Apel and Per Jansson.....

Bayesian Estimation of an Open Economy DSGE Model with Incomplete Pass-Through

by Malin Adolfson, Stefan Laséen, Jesper Lindé and Mattias Villani

Are Constant Interest Rate Forecasts Modest Interventions? Evidence from

an Estimated Open Economy DSGE Model of the Euro Area by Malin Adolfson,

Stefan Laséen, Jesper Lindé and Mattias Villani

Inference in Vector Autoregressive Models with an Informative

Prior on the Steady State by Mattias Villani

Bank Mergers, Competition and Liquidity by Elena Carletti, Philipp Hartmann

and Giancarlo Spagnolo

Testing Near-Rationality using Detailed Survey Data

by Michael F. Bryan and Stefan Palmqvist.

Exploring Interactions between Real Activity and the Financial Stance

by Tor Jacobson, Jesper Lindé and Kasper Roszbach

Two-Sided Network Effects, Bank Interchange Fees,

and the Allocation of Fixed Costs by Mats A. Bergman .....

Trade Deficits in the Baltic States: How Long Will the Party Last?

by Rudolfs Bems and Kristian Jönsson.

Real Exchange Rate and Consumption Fluctuations follwing Trade Liberalization

by Kristian Jönsson

Modern Forecasting Models in Action: Improving Macroeconomic Analyses at Central Banks

by Malin Adolfson, Michael K. Andersson, Jesper Lindé, Mattias Villani and Anders Vredin.....

Bayesian Inference of General Linear Restrictions on the Cointegration Space by Mattias Villani.

2005:189

Forecasting Performance of an Open Economy Dynamic Stochastic General Equilibrium Model

by Malin Adolfson, Stefan Laséen, Jesper Lindé and Mattias Villani

Forecast Combination and Model Averaging using Predictive Measures

by Jana Eklund and Sune Karlsson.

Swedish Intervention and the Krona Float, 1993-2002

by Owen F. Humpage and Javiera Ragnartz

A Simultaneous Model of the Swedish Krona, the US Dollar and the Euro

by Hans Lindblad and Peter Sellin

Testing Theories of Job Creation: Does Supply Create Its Own Demand?

by Mikael Carlsson, Stefan Eriksson and Nils Gottfries.....

Down or Out: Assessing The Welfare Costs of Household Investment Mistakes

by Laurent E. Calvet, John Y. Campbell and Paolo Sodini

Efficient Bayesian Inference for Multiple Change-Point and Mixture Innovation Models

by Paolo Giordani and Robert Kohn

Derivation and Estimation of a New Keynesian Phillips Curve in a Small Open Economy

by Karolina Holmberg

Technology Shocks and the Labour-Input Response: Evidence from Firm-Level Data

by Mikael Carlsson and Jon Smedsaas

Monetary Policy and Staggered Wage Bargaining when Prices are Sticky

by Mikael Carlsson and Andreas Westermark

The Swedish External Position and the Krona by Philip R. Lane

Price Setting Transactions and the Role of Denominating Currency in FX Markets

by Richard Friberg and Fredrik Wilander.....

The geography of asset holdings: Evidence from Sweden

by Nicolas Coeurdacier and Philippe Martin

Evaluating An Estimated New Keynesian Small Open Economy Model

by Malin Adolfson, Stefan Laséen, Jesper Lindé and Mattias Villani .......

The Use of Cash and the Size of the Shadow Economy in Sweden

by Gabriela Guibourg and Björn Segendorf

Bank supervision Russian style: Evidence of conflicts between micro- and macro-

prudential concerns by Sophie Claeys and Koen Schoors 
Optimal Monetary Policy under Downward Nominal Wage Rigidity

by Mikael Carlsson and Andreas Westermark.

Financial Structure, Managerial Compensation and Monitoring

by Vittoria Cerasi and Sonja Daltung

Financial Frictions, Investment and Tobin's q by Guido Lorenzoni and Karl Walentin 2007:208

Sticky Information vs. Sticky Prices: A Horse Race in a DSGE Framework

by Mathias Trabandt.

Acquisition versus greenfield: The impact of the mode of foreign bank entry

on information and bank lending rates by Sophie Claeys and Christa Hainz

Nonparametric Regression Density Estimation Using Smoothly Varying Normal Mixtures

by Mattias Villani, Robert Kohn and Paolo Giordani

The Costs of Paying - Private and Social Costs of Cash and Card

by Mats Bergman, Gabriella Guibourg and Björn Segendorf.

Using a New Open Economy Macroeconomics model to make real nominal

exchange rate forecasts by Peter Sellin.

Introducing Financial Frictions and Unemployment into a Small Open Economy Model

by Lawrence J. Christiano, Mathias Trabandt and Karl Walentin.....

Earnings Inequality and the Equity Premium by Karl Walentin

Bayesian forecast combination for VAR models by Michael $K$ Andersson and Sune Karlsson 2007:216

Do Central Banks React to House Prices?

by Daria Finocchiaro and Virginia Queijo von Heideken.

The Riksbank's Forecasting Performance

by Michael K. Andersson, Gustav Karlsson and Josef Svensson ....

Macroeconomic Impact on Expected Default Freqency

by Per Åsberg and Hovick Shahnazarian

Monetary Policy Regimes and the Volatility of Long-Term Interest Rates

by Virginia Queijo von Heideken

Governing the Governors: A Clinical Study of Central Banks

by Lars Frisell, Kasper Roszbach and Giancarlo Spagnolo

The Monetary Policy Decision-Making Process and the Term Structure of Interest Rates

by Hans Dillén

How Important are Financial Frictions in the U.S. and the Euro Area

by Virginia Queijo von Heideken

2008:223

Block Kalman filtering for large-scale DSGE models by Ingvar Strid and Karl Walentin 2008:224

Optimal Monetary Policy in an Operational Medium-Sized DSGE Model

by Malin Adolfson, Stefan Laséen, Jesper Lindé and Lars E.O. Svensson

Firm Default and Aggregate Fluctuations by Tor Jacobson, Rikard Kindell, Jesper Lindé and Kasper Roszbach

Re-Evaluating Swedish Membership in EMU: Evidence from an Estimated Model

by UIf Söderström

The Effect of Cash Flow on Investment: An Empirical Test of the Balance Sheet Channel

by Ola Melander

Expectation Driven Business Cycles with Limited Enforcement

by Karl Walentin

Effects of Organizational Change on Firm Productivity

by Christina Håkanson 
Sveriges Riksbank

Visiting address: Brunkebergs torg 11

Mail address: se-103 37 Stockholm

Website: www.riksbank.se 